\title{
Mesapalochrus pseudorestrictus, a new genus and species of soft-winged flower beetle of the tribe Apalochrini (Coleoptera: Malachiidae) from Africa
}

\author{
S.E. Tshernyshev ${ }^{1,2}$ \\ ${ }^{1}$ Institute of Animal Systematics and Ecology, Russian Academy of Sciences, Siberian Branch, \\ Frunze Street, 11, Novosibirsk, 630091, Russia.E-mail: sch-sch@mail.ru \\ ${ }^{2}$ Tomsk State University, Lenina prospekt, 36, Tomsk, 634050, Russia.
}

ABSTRACT: A new genus, Mesapalochrus gen.n., is described in the tribe Apalochrini, the type species Mesapalochrus pseudorestrictus Tshernyshev, sp.n. fixed by monotypy in the present paper. Amongst representatives of the tribe, the new genus differs in special male characters, namely: antennae filiform, dentate and sub-flabellate, not widened or impressed in the middle; anterior tarsi with a comb possessing long thin and sharp scallop prongs located above the second segment; anterior tibiae compressed and widened in apical half lacking excavations; intermediate tibiae impressed and flattened in outer side with weakly widened and curved apices; metathorax swollen, slightly impressed in a middle, with white long fine hairs on distal edge, lacking appendage or hair tuft. Illustrations of the special male characters for the new species, which occurs in Tanzania, East Africa, are provided. The placement of the genus in the tribe Apalochrini is discussed.

How to cite this article: Tshernyshev S.E. 2020. Mesapalochrus pseudorestrictus, a new genus and species of soft-winged flower beetle of the tribe Apalochrini (Coleoptera: Malachiidae) from Africa // Invert. Zool. Vol.17. No.2. P.195-201. doi: 10.15298/ invertzool.17.2.09

KEY WORDS: Malachiidae, Apalochrini, Mesapalochrus, taxonomy, new genus, new species, East Africa.

\section{Mesapalochrus pseudorestrictus, новый род и вид жуков малашек трибы Apalochrini (Coleoptera: Malachiidae) из Африки}

\section{С.Э. Чернышёв ${ }^{1,2}$}

\footnotetext{
${ }^{1}$ Институт систематики и экологии животных СО РАН, ул. Фрунзе, 11, Новосибирск, 630091, Россия.E-mail: sch-sch@mail.ru

${ }^{2}$ Томский государственный университет, проспект Ленина, 36, Томск, 634050, Россия.
}

\begin{abstract}
: Из Танзании в Восточной Африке описывается по монотипии новый род и вид жуков малашек Mesapalochrus pseudorestrictus Tshernyshev, gen. et sp.n. От представителей трибы Apalochrini новый род отличается следующими признаками самца: усики зубчатые, дистально слегка гребенчатые, не расширенные или вдавленные посередине, передние лапки с поперечным гребешком, несущим черные тонкие длинные заостренным зубцы, передние голени сжаты с боков и листовидно расши-
\end{abstract}


рены в дистальной части, не имеют вдавлений или выемок, средние голени вдавлены и уплощены с внешней стороны, вершины слабо расширены и изогнуты, заднегрудь вздутая, слегка вдавлена посередине, без придатков, по внешнему краю с рядом белых длинных торчащих волосков. Приводятся иллюстрации специфических структур и внешнего вида самца нового вида, дана карта с указанием места сбора вида. Обсуждается положение нового рода в трибе Apalochrini.

Как цитировать эту статью: Tshernyshev S.E. 2020. Mesapalochrus pseudorestrictus, a new genus and species of soft-winged flower beetle of the tribe Apalochrini (Coleoptera: Malachiidae) from Africa // Invert. Zool. Vol.17. No.2. P.195-201. doi: 10.15298/ invertzool.17.2.09

КЛЮЧЕВЫЕ СЛОВА: Malachiidae, Apalochrini, Mesapalochrus, таксономия, новый род, новый вид, Восточная Африка.

\section{Introduction}

The tribe Apalochrini represents soft-winged flower beetles with typical antennae possessing an extremely small, round or oval second antennomere, usually almost completely hidden by the scape, so that antennae look 10-segmented. The highest species diversity of the tribe occurs in SE Asia, Africa and Australia where species possess a wide spectrum of male characters of importance to differentiate taxa.

Evers $(1987,1990)$ reviewed Afrotropical taxa of the tribe and proposed several genera and analysed special male characters. Mayor (2003) proposed the available name Hadrocnemus Kraatz, 1895 for Oriental species of Apalochrus Erichson, 1840. Due to the Eurasian species distribution of the Apalochrus (Tshernyshev, 2015a), all African species formerly belonging to "Apalochrus sensu lato" should be attributed to Hadrocnemus. Typical characters of the genera remained unclear because of the poorly studied special male characters. However, Epitinus Evers, 1987 was synonymized as a junior synonym of Mesopezus Jacobson, 1911 (Tshernyshev, 2003), the genus Pectinus was synonymised under Dromanthomorphus, two new genera, Mimapalochrus Tshernyshev, 2015 and Oculapalochrus Tshernyshev, 2015 were described for SE Asia (Tshernyshev, 2015b), and the genus Pectapalochrus Tshernyshev, 2016 was described for Eurasia (Tshernyshev, 2016b). The problem of the genus Protapalochrus was discussed (Tshernyshev, 2016c) with a special attention paid to species distribution, since those with tropical areals are included, although the type species, Apalochrus flavolimbatus Mulsant et Rey, 1853, is distributed in Palaearctic from North Africa to East Europe. All species of typical Protapalochrus occur in the Palaearctic (Tshernyshev, 2016c), and those distributed in Africa remain unclear. Recently, a new genus, Acroapalochrus Tshernyshev, 2020, was described from West Africa, which can be compared with the Palaearctic genus Protapalochrus Evers, 1987 but differs in the presence of a tarsal comb in the anterior leg as the main diagnostic character (Tshernyshev, 2020). The taxonomic structure of the tribe is still need of revision.

Amongst Oriental genera, nine possess a tarsal comb in the male, namely: Acroapalochrus Tshernyshev, 2020, Dromanthomorphus Pic, 1921, Hadrocnemus Kraatz, 1895, Hapalochrops Bourgeois, 1908, Mimapalochrus Tshernyshev, 2015, Oculapalochrus Tshernyshev, 2015, Opisthapalochrus Evers, 1987, Setapalochrus Evers, 1988 and Spinapalochrus Pic, 1919.

In addition to a tarsal comb, the genera differ in their male characters as follows: Dromanthomorphus Pic, 1921 and Mimapalochrus Tshernyshev, 2015 possess an appendage in a middle swollen metathorax, Opisthapalochrus Evers, 1987 and Spinapalochrus Pic, 1919 possess an appendage in abdomen, Oculapalochrus Tshernyshev, 2015 differs in its extremely large eyes, Hadrocnemus Kraatz, 1895, Hapalochrops 
Bourgeois, 1908 and Setapalochrus Evers, 1988 differ in their swollen intermediate tibiae provided with appendages or a row of long hairs, and only Acroapalochrus Tshernyshev, 2020 is almost completely lacking protruding characters.

The series of beetles from Africa purchased at the Prague Entomological Fair (Insektenbörse) are similar of external appearance with Dromanthomorphus restrictus Tshernyshev, 2016 which occurs in the Philippines; a detailed study of the male from Africa presented new characters which differentiated it the genus discussed above, namely: metathorax swollen, simple, lacking appendage; intermediate tibiae not swollen, slightly widened and curved apically; apical tibiae compressed and leaf-shape widened in apical lobe; antennae dentate and subflabellate; aedeagus almost completely straight, narrow and elongate, with elongate narrow and rounded at the tip lamella; inner sac wide and short, located in the middle of the aedeagus and formed with two black lobes of small denticles; tarsi different due to triangular 2nd tarsomere possessing distinct transverse comb with long thin and sharp scallop prongs. These characters reveal that this is a new species and a member of a separate genus, described below as Mesapalochrus pseudorestrictus Tshernyshev, sp.n.

\section{Material and methods}

The beetles were studied using an Amscope trinocular stereomicroscope (Ultimate Trinocular Zoom Microscope 6.7X-90X Model ZM2TY) and digital photographs were taken using a Carl Zeiss Stemi 2000 trinocular microscope and the AxioVision programme. Male genitalia, embedded in DMHF (Dimethyl hydantoin formaldehyde), were mounted onto a transparent card and pinned under the specimen. Specimens have been deposited in the author's collection $(\mathrm{SCH})$, which housed in the Institute of Animal Systematics and Ecology, Siberian Branch of the Russian Academy of Sciences, Novosibirsk, Russia.

\section{Results}

Family Malachiidae Fleming, 1821

Subfamily Malachiinae Fleming, 1821

Tribe Apalochrini Mulsant and Rey, 1867

\section{Mesapalochrus Tshernyshev gen.n.}

Type species: Mesapalochrus pseudorestrictus Tshernyshev, sp.n. fixed by monotypy in the present paper.

DIAGNOSIS. This is based on male special characters only. Size moderate (c. 4.0-4.3 mm) with the body elongate, parallel-sided and slightly expanded posteriorly. Upper side metallic blue-green and underside black, antennae yellow. Surface of head and pronotum evenly finely punctured, with indistinct microsculpture, elytra densely and coarsely punctate, covered with grey long sparse erect pubescence. Antennae serrate and weakly flabellate, with triangular intermediate antennomeres (Fig. 1,C), 2.4 $\mathrm{mm}$ long, 1 st segment weakly enlarged, clavate, 2nd segment small, invisible, 3rd antennomere triangular, as long as the 1 st antennomere, 3rd antennomere slightly wider, $4^{\text {th }}-9$ th antennomeres narrow in the middle with an expanded outer edges forming "flabellate" part of the antenna, apical one is elongate, sub-oval, widened at apex with oval flat impression in apical outer edge. Head small, flat, narrower than pronotum, interocular area flat, eyes simple, round, not large, slightly protruding. Pronotum not narrowed at base, almost completely equilateral and sub-quadrate with evenly rounded angles, narrowly depressed at the base, with posterior margin weakly elevate; anterior side slightly protruding, posterior straight; lateral sides evenly rounded; marginal sides distinct. Elytra sub-parallel, slightly expanded just behind the basal fourth, at base slightly wider than pronotum; humeri small, distinct and weakly protruding; apices wide, rounded, simple, straight; disc distinctly marginate on external sides and along suture, edging of suture slightly elevate at the middle; epipleura narrow. Hind wings normally developed. Anterior tarsi with the 2 nd segments possessing distinct transverse 


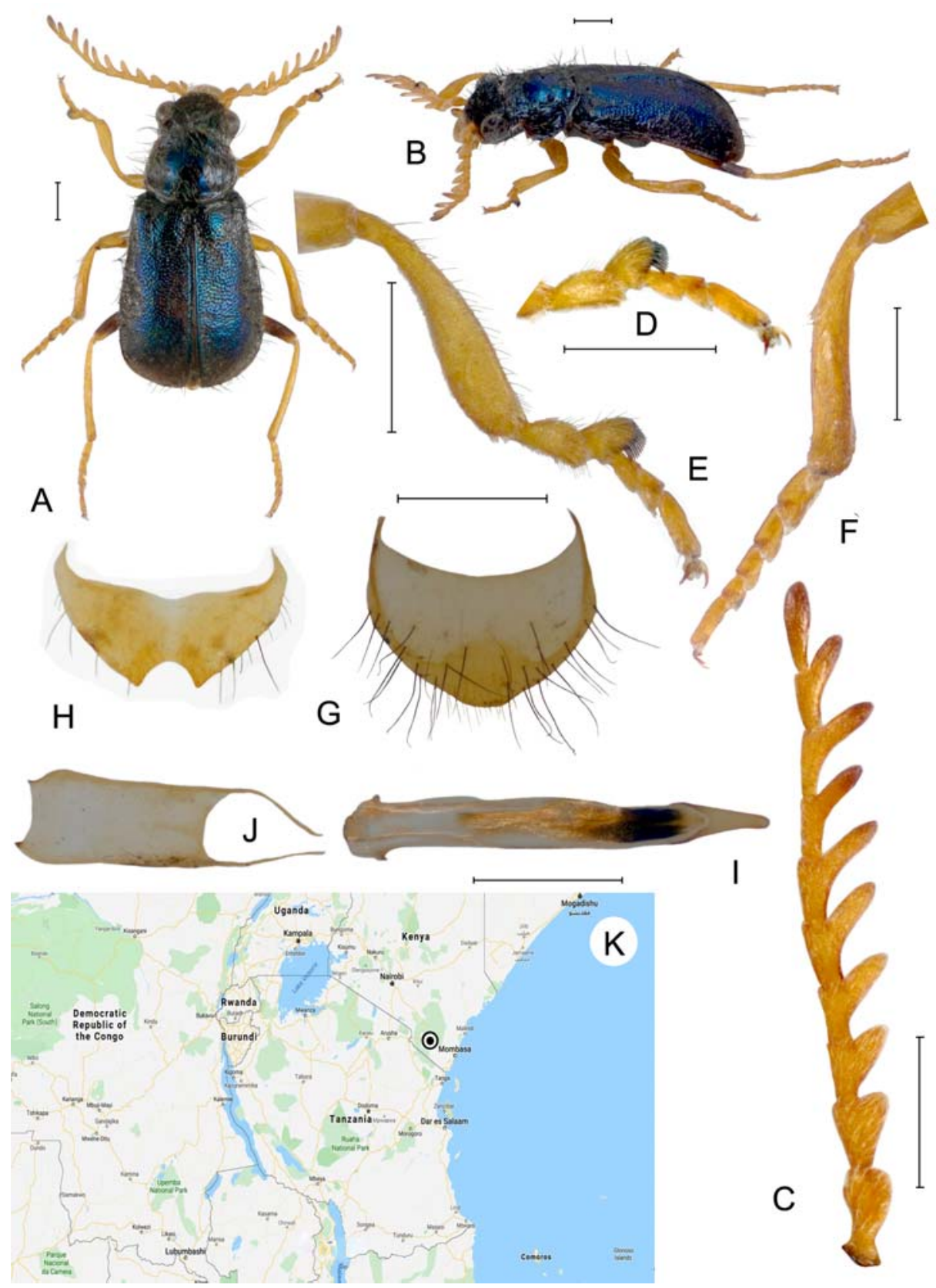

Fig. 1. Mesapalochrus pseudorestrictus Tshernyshev gen. et sp.n., holotype, male. A - external appearance, dorsal view; B - external appearance, lateral view; C - left antenna; D - left anterior tarsus; E - tibia and tarsus of left intermediate leg; $\mathrm{F}$ - tibia and tarsus of right anterior leg; $\mathrm{G}$ - pygidium; $\mathrm{H}$ - ultimate abdominal ventrite; I - aedeagus, dorsal view; J - tegmen; $\mathrm{K}$ - distribution map. Scale bar $0.5 \mathrm{~mm}$. Рис. 1. Mesapalochrus pseudorestrictus Tshernyshev gen. et sp.n., голотип, male. А - внешний вид дорзально; В - внешний вид латерально; C - левый усик; D - левая передняя лапка; Е — голень и лапка левой передней ноги; F — голень и лапка левой средней ноги; $\mathrm{G}$ - апикальный тергит; H апикальный стернит; I — эдеагус, дорзально; J — тегумен; K — карта распространения. Масштаб 0,5 мм. 
comb with long thin and sharp scallop prongs, anterior tibiae compressed and widened apical half lacking excavations (Fig. 1,E), intermediate tibiae impressed and flattened in outer side with weakly widened and curved apices (Fig. $1, F)$, posterior tibiae simple, straight; all femora slightly widened and simple, lacking emarginations or indentations; trochanters simple, lacking teeth, elongate. Metathorax swollen, slightly depressed in a middle, with white long fine hairs on distal edge, lacking appendage or hair tuft. Pygidium undivided, evenly rounded and narrowed distally, with long black setae (Fig. $1, \mathrm{G})$; 8th ultimate abdominal ventrite narrow, transverse, evenly rounded and narrowed distally, with round emargination in middle and sharp apices above it (Fig. 1,H); aedeagus almost completely straight, narrow and elongate, with elongate narrow and rounded at the tip lamella; inner sac wide and short, located in a middle of the aedeagus and formed with two black lobes of small denticles (Fig. 1,I). Tegmen narrow, strongly elongate, with short thin parameres (Fig. 1,J).

COMPARATIVE DIAGNOSIS. A species of the genus is similar to representatives of Protapalochrus Evers, 1987 and Acroapalochrus Tshernyshev, 2020, and differ in the anterior tibiae compressed and widened in apical half lacking excavations (Fig. 1,E), intermediate tibiae impressed and flattened in outer side with weakly widened and curved apices (Fig. 1,F), serrate antennae with simple, not canaliculated, intermediate antennomeres, and aedeagus, narrowed and elongate distally (Fig. $1, \mathrm{I})$.

ETYMOLOGY. The name of the genus is a

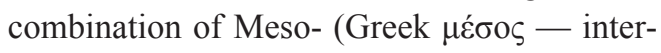
mediate) with regard to the transitive character of the new genus between congeners in the tribe, and Apalochrus - a name of the nominative genus of the tribe Apalochrini.

NOTES. The genus occurs in Tanzania (East Africa, Kenya, Tsavo National Park, M. pseudorestrictus Tshernyshev, sp.n.).

\section{Mesapalochrus pseudorestrictus \\ Tshernyshev, sp.n. \\ Fig. 1 A-K.}

MATERIAL. Kenya: Holotype, male, Tsavo East National Park, Voi town, 9०46'S; 3846’E; 22.XI-2.XII.1996, M. Snížek leg.; allotype, female, idem; paratypes, 5 males, 6 females, idem.

DESCRIPTION. Holotype, male (Fig. 1A, B). Body elongate, sub-parallel, slightly widened and expanded posteriorly.

Antennae, clypeus, labrum, labium, mandibles excepting black apices, palpi, tarsi, ventrites, legs excepting black denticles of tarsal comb and apical third of posterior femora yellow, other body parts black; upper surface of head, pronotum and elytra with blue-green metallic luster. Surface evenly covered with sparse grey long erect pubescence. Vesicles yellow, and thoracic mesepimera black.

Head narrower than pronotum, flat, interocular area flat, eyes simple, round, not large, slightly protruding, frons flat; genae short and straight; clypeus narrow, transverse, straight; labrum slightly more elongate, transverse; palpi simple with apical segment widened and triangular; surface of head evenly finely punctured, with indistinct microsculpture, densely covered with light fine adpressed hairs on clypeus and grey long sparse pubescence.

Antennae serrate and weakly flabellate, with triangular intermediate antennomeres (Fig. 1,C), $2.4 \mathrm{~mm}$ long, expanding to the middle of elytra; 1 st segment weakly enlarged, clavate, 2 nd segment small, round, almost completely invisible, strongly hidden by the 1st segment, 3rd antennomere triangular, as long as the 1st antennomere, 3rd antennomere slightly wider, $4^{\text {th }}-9$ th antennomeres narrow in the middle with expanded outer edges forming "flabellate" part of the antenna, apical one is elongate, sub-oval, widened at apex with oval flat impression in apical outer edge; surface sparsely covered with short, light adpressed pubescence.

Pronotum not narrowed at base, almost completely equilateral and sub-quadrate with evenly rounded angles, narrowly depressed at the 
base, with posterior margin weakly elevate; anterior side slightly protruding, posterior straight; lateral sides evenly rounded; margination of sides distinct; surface sparsely and finely punctured, with smooth microsculpture, shining, evenly covered with long semi-erect grey hairs.

Scutellum rectangular, small and narrow, transversal, almost completely covered by pronotum, sparsely punctured and covered with sparse pubescence.

Elytra sub-parallel, slightly expanded just behind the basal fourth, at base slightly wider than pronotum; humeri small, distinct and weakly protruding; apices wide, rounded, simple, look cut straight; disc distinctly marginate on external sides and along suture, edging of suture slighlty elevate at the middle; epipleura narrow; surface shining, densely and coarsely punctured, with distinct microsculpture, evenly covered with grey long erect pubescence.

Hind wings normally developed.

Legs thin, not short; posterior femora not reaching elytral apices; anterior tibiae compressed and widened apical half lacking excavations (Fig. 1,E), intermediate tibiae impressed and flattened in outer side with weakly widened and curved apices (Fig. 1,F), posterior tibiae simple, straight; all femora slightly widened and simple, lacking emarginations or indentations; trochanters simple, lacking teeth, elongate; all tarsi 5-segmented, intermediate tarsomeres slightly compressed, apical one flattened, not long, first tasomere elongate, triangular and the largest in all legs, 2nd segment in anterior tarsi triangular, with transversal comb above possessing long thin and sharp scallop prongs (Fig. $1, \mathrm{G}, \mathrm{H})$, in intermediate and posterior legs it is 1.5 times shorter than the 1 st tarsomere, 1.5 times as long as the 4th and slightly longer than 3rd; claw-segment somewhat longer than 1st tarsomere in all legs; claws thin, narrow and sharp, with round transparent membrane at base.

Ventral body surface sparsely punctured with distinct microsculpture, dull, evenly covered with fine, adpressed white pubescence; metathorax swollen, slightly impressed in a middle, with white long fine hairs on distal edge, lacking appendage of hair tuft. Pygidium undivided, evenly rounded and narrowed distally, with long black setae (Fig. 1,G); 8th ultimate abdominal ventrite narrow, transverse, evenly rounded and narrowed distally, with round emargination in middle and sharp apices above it (Fig. 1,H); aedeagus almost completely straight, narrow and elongate, with elongate narrow and rounded at the tip lamella; inner sac wide and short, located in a middle of the aedeagus and formed with two black lobes of small denticles (Fig. 1,I). Tegmen narrow, strongly elongate, with short thin parameres (Fig. 1, J).

Length $4.0 \mathrm{~mm}$, width (at elytral base) 1.5 $\mathrm{mm}$.

Female differs in having simple filiform slightly serrate antennae, small and narrow tarsi which lack a tarsal comb, slightly wider body. Length 4.0-4.3 mm, width (at elytral base) 1.6$1.7 \mathrm{~mm}$.

DISTRIBUTION. The species is known from the type locality only, Kenya, Tsavo National Park (Fig. 1,K).

Acknowledgements. The author is gratitude to Prof. Mark Seaward (Bradford University, U.K.) for the linguistic revision of the text. This study was supported by the Federal Fundamental Scientific Research Programme for 2013-2020, grant No. VI.51.1.5 (AAAA-A16116121410121-7).

\section{References}

Evers A.M.J. 1987. Synopsis der Gattung Apalochrus Er. und der verwandten Gattungen der Welt (Col., Malachiidae). 63. Beitrag zur Kenntnis der Malachiidae // Annalen Zoologische Wetenschappen. Bd.253. S.173.

Evers A.M.J. 1990. Neue Malachiidae der orientalischen Region aus dem Zoologisk Museum, Kopenhagen. (75. Beitrag zur Kenntnis der Malachiidae) // Entomologische Blätter für Biologie und Systematik der Käfer. Bd.86. S.85-90.

Mayor A.J. 2003. Nomenclatorial corrections for Dasytidae and Malachiidae (Coleoptera) // Insecta Mundi. Vol.17. Nos 1-2. P.85-96.

Tshernyshev S.E. 2003. [Epitinus Evers, 1987, a junior synonym of Mesopezus Jacobson, 1911 (Coleoptera, Malachiidae)] // Euroasian Entomol. J. Vol.2. No.1. P.61-62 [in Russian]. 
Tshernyshev S.E. 2015a. A review of species of the genus Apalochrus Erichson (Coleoptera, Malachiidae) // Zootaxa. Vol.3941. No.3. P.358-374. http://dx.doi. org/10.11646/zootaxa.3941.3.3

Tshernyshev S.E. 2015b. Soft winged flower beetles (Coleoptera, Malachiidae) of the Himalaya region, with notes on Apalochrini // Biodiversitat und Naturasstattung im Himalaya. Vol.5. P.389-405.

Tshernyshev S.E. 2016a. The genus Dromanthomorphus Pic, 1921 (Coleoptera, Cleroidea: Malachiidae) in South-East Asia // Zootaxa. Vol.4139. No.4. P.551565. http://doi.org/10.11646/zootaxa.4139.4.7
Tshernyshev S.E. 2016b. [Pectapalochrus gen. nov., a new genus of soft-winged flower beetles of the tribe Apalochrini (Coleoptera, Malachiidae)] // Zoologicheskii zhurnal. Vol.95. No.3. P.300-305 [in Russian with English abstract]. DOI: 10.7868/ S0044513416030041

Tshernyshev S.E. 2016c. A review of species of the genera Protapalochrus Erichson and Paratinoides L. Medvedev (Coleoptera, Malachiidae)//Zootaxa. Vol.4139. No.3. P.369-390.

Responsible editor K.G. Mikhailov 